Lesław Polny*

\title{
Prediction Cadastral Tax Implementation in the Aspect of Experience Other Countries
}

\section{Introduction}

Cadastral tax is long, but not quite glorious history [7]. Some U.S. states implement and enforce it already in final years of eighteenth century. In nineteenth century and also in United States, idea a tax on value of possess land propagated by Henry George - American writer, politician, economist and the most influential proponent implementation this assessment. He argued, that construction tax on value of possessed land they, will eliminate all other taxable [7]. Modernist at that time, cadastre system in Europe, was constructed in mid-nineteenth century, when register of this type created in France and Austria-Hungary. Parallel to these developments in various German states were formed different formal and legal solutions for cadastral tax. However, it only unified in 1936. Currently, system only addictive tax of property values is in many countries of the world including Europe Central, Western and Scandinavia.

One of the biggest organizations for people professionally involved in real estate appraisal and taxation is the "International Association of Assessing Officers IAAO", aimed at promoting innovation (scientific research) and good practice, as well as providing education on assessing real estate and the taxation policy [1].

In Poland while tax system is dependent on area land and/or superficies a building or premises. Thus, owner of villa with an area equal $200 \mathrm{~m}^{2}$, localized on 10 acres plot in Warsaw's downtown, are now paying little higher (compared to growth cadastral tax) then this one, which is charged to owner 10 acres plot built detached house with an area of $200 \mathrm{~m}^{2}$, located in eastern part of Poland, even though value of the first property, even ten times value of other property. In this regard, it is fairer cadastral tax, but in addition to its advantages should also take into account quite a lot disadvantages. Prediction its implementation, in terms of empirical data from other European countries, will be answer to question: whether initiation tax of value

* AGH University of Science and Technology, Faculty of Mining Surveying and Environmental Engineering, Krakow, Poland 
property is not peculiar triumph form over content and what should be the rate tax to get a compromise between old (relatively low) rates and future, more righteous? Development responses to this question will serve conducted later in this paper, a review of domestic political and economic situation as well as data from European Statistical Office. On the basis of this review finds proposed rate estimated cadastral tax, hereafter called as an "ad valorem tax" (Latin: of value).

\section{Prognosis Introduction a Cadastral Tax in Poland}

Accordance with project entitled Assumptions of the National Urban Policy to 2020, prepared by Ministry of Regional Development, tax of property value or at least addicted to it, will be introduced to year shown in title. Difference between tax of property value and tax addicted of property value is diametrical. The first is of course identical cadastral tax, whose only criterion is property value, estimated in process mass appraisal. The second one is not defined. So we can only presume that form will take. Most likely will be striving for a compromise between current form taxation and ad valorem tax. This means that tax on area real estate will be adjusted by special rates or cadastral value will be only component more complex form calculating property tax, which will also be dependent on macroeconomic factors.

Forecast of a tax on real estate values refer also to existing legal system in Poland. Now in Law on Real Estate in work IV, chapter 2 was devoted to mass appraisal and its relation Council of Ministers in June 2005, issued a regulation on this process. That legislation, while not fully resolve question of valuation for tax register, but are a solid foundation to make this tribute. An interesting question in context these considerations is date announcement the Regulation, i.e. only slightly more than one year of Polish entry into European Union. Although EU "controls" only (or until) amount of indirect taxes, it may exert a pressure on ruling, regarding implementation ad valorem tax, which is a practical realization provisions of the Regulation.

Given all of these issues in this chapter and scale government debt is still growing, it is clear impose a tax on real estate values.

\section{Advantages and Disadvantages of Cadastral Tax}

Tribute from value property, despite the fact that its implementation is great unknown, raises a lot of controversy among Polish society. Cadastral taxes like everyone else, has an alter ego manifested in above all its pros and cons.

Anticipated benefits of ad valorem tax for Polish reality undoubtedly are:

- greater justice than the input tax on area,

- rational management and investing in real estate,

- greater interest in local government, investing in real estate, because, when envisaged, would guarantee them a higher cash proceeds from the just tribute. 
List of defects cadastral tax is much longer than advantages presented above. Among the most frequently mentioned his shortcomings stand out:

- complicated way of modeling cadastral value,

- very high implementation costs,

- necessity creation real estate cadastre; the system complete information about land, buildings and parts of this buildings (premises),

- relative short topicality estimated cadastral values, so they need frequent updates, which is very cost prohibitive, the properties should be physically inspected and revalued at least once every four to six years [6],

- increase in cost of rental properties, because its owners will diversify growth upkeep property costs trough money tenants,

- risk of a massive sale real estate by persons with low incomes relative to estimated cadastral value,

- exorbitantly higher amount tax than the current value of property tax on area.

Furthermore mass appraisal requires complete and accurate data, effective valuation models, and the proper management of resources [1]. Therefore, the success of a tax on value property depends primarily on efficient system mass appraisal real estate, balanced taxation system and conditions social-economic [11].

\section{Ad Valorem Tax Based on Selected Countries}

The taxable amount of land tax in Germany is market value of special reduced rates, which depend on type property and region country. They oscillate in range of $2.6 \%$ to $1 \%$. Finally, the same value is multiplied by tribute special indexes vary by municipality. Result of this process is effective amount tax rate, the value of which varies between $0.98 \%$ and $2.84 \%$, giving an average $1.90 \%$ property value. German lawmakers predicted, however, a wide range tax exemptions among different social institutions, public or religious premises.

Implemented in 1993, British "council tax", levied by local authorities to tax residential property. This tax in England is progressive, manifested by low property tax base of cheaper, better of more expensive. This base is grouped in eight-scale, which are assigned to sole criterion of real estate, which is value. Average rate for tax base of middle ceiling value is $1 \%$. In years from 2010 to 2012 council tax was ranked at same level in 1439 pounds [7], while in 2013 only increased by five pounds, which in recent years is only "cosmetic" changes. As in Germany, here also legislature anticipated tax exemptions, but the concept is much more directed to "average citizen", because tax credits are covered among other things, students, disabled persons and single dwelling involved. The second tax, called "non-domestic rate" includes real estate held for carrying out the work arising from business. It involves calculating fractional part of annual income from rent for a property. In Wales, the tax rate was $44 \%$, in England and $48 \%$ of rental income. 
In USA, tax called "ad valorem", is different in every state, but assumed that it is at the level of $1.04 \%$ (average) market value property. The highest was in 2009 in New Jersey $(1.89 \%)$ and New Hampshire $(1.86 \%)$ and lowest in Louisiana $(0.18 \%)$ and Hawaii $(0.26 \%)$ [7]. Interesting are the results of a referendum held in North Dakota, where about $75 \%$ local population in favor maintaining current form taxation. It's a completely different approach to cadastral tax than that observed in Central and Eastern Europe. In USA, there are also tax exemptions such as for veterans, religious institutions or for certain economic activities.

Cadastral tax also applies in Baltic countries. In 1993, Estonia implemented a tax on owned land. Powers on local budgets, and it is local authority shall determine amount tax rates, which range from $1 \%$ o to as much as $2.5 \%$ estimated annual value land. On the other hand, in Lithuania amounted to $1.5 \%$ of land being the subject private ownership, and from $0.3 \%$ to $1.0 \%$ value of real estate construction. In both countries, there is a rich catalog of tax deductions and exemptions, but also in Lithuania since January 1, 2012 was introduced separate taxation of large estates. Homeowners in excess one million litas (based on Polish currency is about 1250000 PLN) pay annually $1 \%$ of their value. In Latvia, ad valorem tax rate is more uniform, because rate of land, along with a building, is $1.5 \%$. Progressive tax is revealed only to dwellings that are classified in terms of their value in three-point scale: $0.2 \%, 0.4 \%$ and $0.6 \%$. In Latvia discussed tribute extremely drastic is the uncultivated agricultural land. Owner fallow must pay up 3\% value its real estate. In this pattern, as recently reported by media, Polish Ministry of Finance plans to introduce an annual fee of agricultural wasteland, oscillating between 100 and 1000 PLN.

Cadastral tax in Belgium and France looks different terms described above. In both countries, tribute is determined from value property, but calculated as a percentage of real income, which supposedly property is able to provide its owner within a year [7]. In Belgium, taxable amount is indexed annually by a specialized department called cadastral administration. Income flowing from tax affects budget of local governments at various levels. Take for example in Brussels, where total tax is $39.24 \%$ tax base, of which $1.25 \%$ is for region, $7.36 \%$ for department, municipality and remainder, which is $30.63 \%$. Statutory discount from tax shall, inter alia disabled, disabled or families (married with children).

The same is true in France. At beginning of each calendar year, state sends to local governments the basis for cadastral taxes and their rates shall be adopted by local government is in an adequate amount of their financial needs. The highest rates are biased in Mizoen and Fontanes-de-Sault (about 86\% tax base), and the lowest in Neuilly-Sur-Seine and Thiverval-Grignon (about 9\% tax base). To emphasize participation local authorities in placement of level cadastral tax, in the center of Paris, ad valorem tax rate is $12.88 \%, 25.38 \%$ in Lyon, Marseille and $37.65 \%$. In France there is also a tax on a progressive, but here only for large estates, i.e. from 1.3 million to 3 million rate equal to $0.25 \%$ value and $0.5 \%$ against property over 3 million. 


\section{Proposed Rates Cadastral Tax for Polish}

This chapter provides an original proposal to tax on value property you are confronted with current tax system, and at rate of one percent, as the mostly forecast in media.

In view of issues raised in previous chapters questions regarding the introduction a cadastral tax, developed a proposal for its rates, referring to European countries, which have already effectively operating a tax system based on property values. For Polish and states that, collected data on average monthly earnings, average prices $1 \mathrm{~m}^{2}$ of property as well as the average of tax rate (for all of the countries except Polish). These data due to methodology of testing by European Statistical Office, are authoritative empirical data, in terms of determining ad valorem tax. They are summarized in Table 1.

Table 1. Summary data needed to estimate tax base

\begin{tabular}{|c|l|c|c|c|c|c||}
\hline \multirow{2}{*}{$i$} & \multirow{2}{*}{ Country } & \multicolumn{2}{|c|}{ Average monthly earnings $d_{i}$} & \multicolumn{2}{|c||}{ Average price for $1 \mathrm{~m}^{2} c_{i}$} & Tax rate $p_{i}$ \\
\cline { 3 - 7 } & & {$[$ EUR] } & {$[$ [PN] } & {$[$ EUR] } & {$[$ PLN] } & {$[\%]$} \\
\hline \hline 1 & England & 2648 & 10969 & 14421 & 59745 & 1.00 \\
\hline 2 & Estonia & 867 & 3591 & 2386 & 9885 & 1.30 \\
\hline 3 & Greece & 1681 & 6964 & 6622 & 27434 & 0.03 \\
\hline 4 & Spain & 2113 & 8753 & 3932 & 16290 & 0.85 \\
\hline 5 & Netherlands & 2682 & 11112 & 3579 & 14827 & 0.15 \\
\hline 6 & Ireland & 3537 & 14652 & 5483 & 22716 & 1.50 \\
\hline 7 & Lithuania & 654 & 2710 & 2406 & 9968 & 0.65 \\
\hline 8 & Latvia & 696 & 2882 & 2286 & 9471 & 1.50 \\
\hline 9 & Germany & 2475 & 10253 & 2882 & 11940 & 1.90 \\
\hline 10 & Sweden & 3051 & 12641 & 7842 & 32489 & 1.25 \\
\hline 11 & Poland & 809 & 3352 & 3546 & 14691 & - \\
\hline
\end{tabular}

Source: own study based on [4]

In order to standardize units of currency, data from European Statistical Office expressed in a common currency euro (EUR), converted into the national unit (PLN) at exchange rate of 4.1429 [8].

Problematic in terms of determining basis ad valorem tax, which is based on an analysis European markets is considerable variation in monthly average wages and price of $1 \mathrm{~m}^{2}$ property. To make a kind of normalization purchasing power of citizens in individual countries, assessed dependency between average monthly earnings and average unit price real estate. This dependency is illustrated in graph below (Fig. 1), which is monetary unit adopted the common European currency (EUR). 


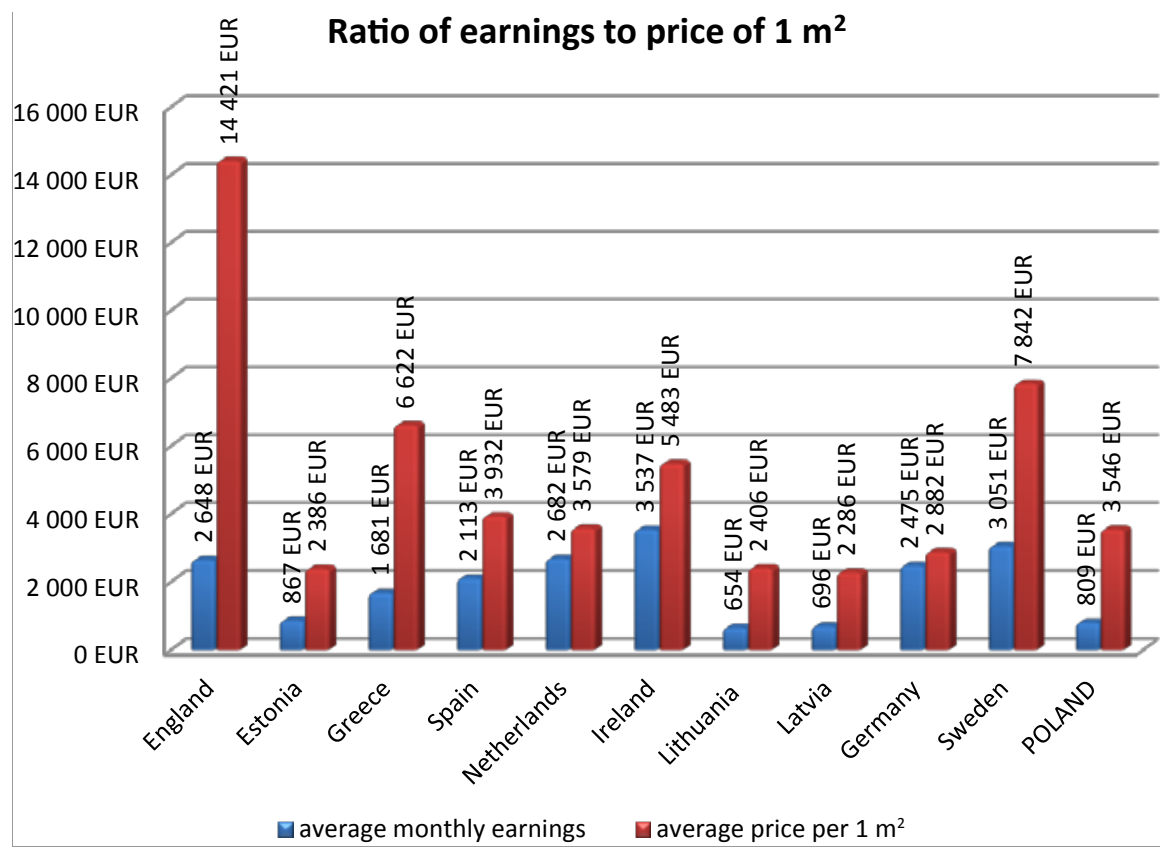

Fig. 1. Visualization of average monthly earnings compared to price of $1 \mathrm{~m}^{2}$ property Source: own study based on [4]

Possibility purchasing power of citizens $i$-th state $\left(S_{m_{i}}\right)$ in Table 2 are set on a scale of one month as a mutual relation average national income of $i$-th country $\left(d_{i}\right)$ and unit price of $1 \mathrm{~m}^{2}$ property in $i$-th state $\left(c_{i}\right)$, using formula in the following form:

$$
S_{m_{i}}=\frac{d_{i}}{c_{i}}
$$

In order to estimate purchasing power of citizens all country, in a one year period $\left(S_{r_{i}}\right)$, purchasing power on a monthly basis multiplied by 12 (the number of months in a year), thus implementing the following equation:

$$
S_{r_{i}}=12 \cdot S_{m_{i}}=12 \cdot \frac{d_{i}}{c_{i}}
$$

Due to the fact that it is for Polish tax base is determined, average ability to purchase $\left(\bar{S}_{r}\right)$ and average tax rate $(\bar{p})$ was estimated on basis of all countries surveyed $(n)$, with exception of Polish (hence the formula set out in following record " $n-1$ "):

$$
\begin{aligned}
& \bar{S}_{r}=\frac{1}{n-1} \cdot \sum_{i=1}^{n-1} S_{r_{i}} \\
& \bar{p}=\frac{1}{n-1} \cdot \sum_{i=1}^{n-1} p_{i}
\end{aligned}
$$


Results calculations designed to estimate size needed for determining tax base of property value, as shown in Table 2 .

Table 2. Estimating size needed to determine tax rate cadastral

\begin{tabular}{|c|c|c|c|c|c|c|c|c|c|c|c|}
\hline$i$ & 1 & 2 & 3 & 4 & 5 & 6 & 7 & 8 & 9 & 10 & 11 \\
\hline Country & 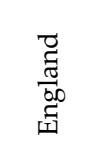 & 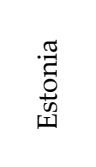 & 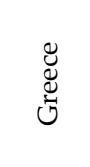 & $\begin{array}{l}\text { శ్ } \\
\text { के }\end{array}$ & 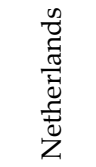 & 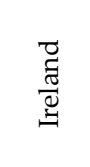 & 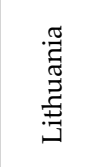 & 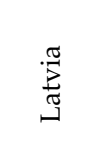 & 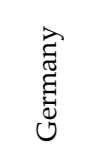 & 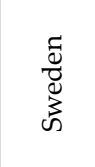 & $\begin{array}{l}\vec{E} \\
\vec{E} \\
0 \\
0\end{array}$ \\
\hline$S_{m_{i}}$ & 0.1836 & 0.3633 & 0.2538 & 0.5373 & 0.7494 & 0.6450 & 0.2719 & 0.3043 & 0.8587 & 0.3891 & 0.2282 \\
\hline$S_{r_{i}}$ & 2.20 & 4.36 & 3.05 & 6.45 & 8.99 & 7.74 & 3.26 & 3.65 & 10.30 & 4.67 & 2.74 \\
\hline $\bar{S}_{r}$ & \multicolumn{10}{|c|}{5.47} & \\
\hline$p_{i}$ & 1.00 & 1.30 & 0.03 & 0.85 & 0.15 & 1.50 & 0.65 & 1.50 & 1.90 & 1.25 & \\
\hline $\bar{p}$ & \multicolumn{10}{|c|}{1.01} & \\
\hline
\end{tabular}

Basis of cadastral tax $\left(p_{p}\right)$, in proposed method, it was established by calculating ratio of product of purchasing power Poles $\left(S_{r_{11}}\right)$ and average tax rate $(\bar{p})$ to average citizens purchasing capabilities countries surveyed $\left(\bar{S}_{r}\right)$. Basis for this is determined for realization, therefore, following formula:

$$
p_{p}=S_{r_{11}} \cdot \frac{\bar{p}}{\bar{S}_{r}}
$$

Substituting to formula (5) sizes estimated in Table 2, were obtained percentage rate tax on value property equal to $5.1 \%$.

$$
p_{p}=2.74 \cdot \frac{1.01 \%}{5.47}=0,51 \%
$$

Estimated tax rate, however, is adequate only to appraisal zones where average cadastral value is equal to price of $1 \mathrm{~m}^{2}$ real estate, provided by European Statistical Office, which is 14691 PLN. It is therefore necessary adjustment tax base determined based on estimated cadastral values unit in the zone appraisal.

For purposes of this study were estimated ten cadastral value of land built detached house, located in Rzeszow, within the registration 219-Wilkowyja. Table 3 summarizes basic information, which is basis for determining regional tax rate in accordance with established further assumptions. Also shows calculated tax rate adequate to current methodology of defining. 
Table 3. Summary size necessary to establish regional tax rates and compare its estimates of current system

\begin{tabular}{|c|c|c|c|c|c|c|c|c||}
\hline \multirow{2}{*}{$k$} & $\begin{array}{c}\text { Parcel } \\
\text { number }\end{array}$ & $\begin{array}{c}\text { Area of } \\
\text { land }\end{array}$ & $\begin{array}{c}\text { Area of } \\
\text { building }\end{array}$ & $\begin{array}{c}\text { Unit } \\
\text { cadastral } \\
\text { value }(\overline{W K})\end{array}$ & $\begin{array}{c}\text { Cadastral } \\
\text { value }\end{array}$ & $\begin{array}{c}\text { Tax on } \\
\text { land }\end{array}$ & $\begin{array}{c}\text { Tax on } \\
\text { building }\end{array}$ & $\begin{array}{c}\text { Sum tax on } \\
\text { land and } \\
\text { building }\end{array}$ \\
\cline { 3 - 9 }$\left[\mathrm{m}^{2}\right]$ & {$\left[\mathrm{m}^{2}\right]$} & {$\left[\mathrm{PLN} / \mathrm{m}^{2}\right]$} & {$[\mathrm{PLN}]$} & {$[\mathrm{PLN}]$} & {$[\mathrm{PLN}]$} & {$[$ PLN] } \\
\hline \hline 1 & 991 & 1643 & 143 & 5260.67 & 752275 & 361.46 & 85.80 & 447.26 \\
\hline 2 & 712 & 987 & 107 & 5435.90 & 581641 & 217.14 & 64.20 & 281.34 \\
\hline 3 & 1185 & 950 & 120 & 4844.84 & 581381 & 209.00 & 72.00 & 281.00 \\
\hline 4 & $237 / 1$ & 2970 & 123 & 6173.57 & 759349 & 653.40 & 73.80 & 727.20 \\
\hline 5 & $758 / 2$ & 2019 & 106 & 4592.28 & 486782 & 444.18 & 63.60 & 507.78 \\
\hline 6 & 1257 & 671 & 80 & 5449.12 & 435929 & 147.62 & 48.00 & 195.62 \\
\hline 7 & 637 & 783 & 102 & 5195.28 & 529918 & 172.26 & 61.20 & 233.46 \\
\hline 8 & 1572 & 2130 & 108 & 6099.53 & 658750 & 468.60 & 64.80 & 533.40 \\
\hline 9 & 969 & 692 & 117 & 4879.44 & 570895 & 152.24 & 70.20 & 222.44 \\
\hline 10 & 735 & 2297 & 99 & 5427.43 & 537316 & 505.34 & 59.40 & 564.74 \\
\hline \hline
\end{tabular}

The adjustment of tax base is to determine regional tax rate $\left(p_{\text {reg }}\right)$, equal to quotient of product of tax rate for entire Polish $\left(p_{p}\right)$ and average unit cadastral value $(W K)$ in the zone appraisal, average price of $1 \mathrm{~m}^{2}$ property $\left(c_{11}\right)$, provided by European Statistical Office. In symbolic notation this equation takes following form, where $k$ is a number properties from database and $m$ is abundance pool of all properties included in analysis:

$$
\begin{gathered}
p_{\text {reg }}=\frac{p_{p} \cdot \overline{W K}}{c_{11}}=\frac{p_{p}}{c_{11} \cdot m} \cdot \sum_{k=1}^{m} W K_{m} \\
p_{\text {reg }}=\frac{0.51 \% \cdot 4437 \mathrm{PLN}}{14691 \mathrm{PLN}}=0.15 \%
\end{gathered}
$$

On the basis of considerations in this section, estimated expected value cadastral tax on real estate in database. These values were determined in relation to rate of $1.00 \%, 0.51 \%$ and $0.15 \%$, which is already converted to appropriate appraisal zone, i.e. precinct Wilkowyja. Also estimated amount property tax adequate current form of taxation, assuming current rates in Rzeszow, i.e. 0.22 PLN for land and 0.60 PLN for detached house [12] (habitable). Results of these calculations and ratio of projected value ad valorem tax to current tax rates are summarized in Table 4. 
Table 4. Summary of tax rates on real estate values

\begin{tabular}{||c|c|c|c|c|c|c|c|c||}
\hline$k$ & $\begin{array}{c}\text { Parcel } \\
\text { number }\end{array}$ & $\begin{array}{c}\text { Tax on } \\
\text { land } \\
{[\text { PLN] }}\end{array}$ & $\begin{array}{c}\text { Cadastral } \\
\text { tax } 1.00 \% \\
{[\text { PLN] }}\end{array}$ & Ratio & $\begin{array}{c}\text { Cadastral } \\
\text { tax=0.51\% } \\
{[\text { PLN] }}\end{array}$ & Ratio & $\begin{array}{c}\text { Cadastral } \\
\text { tax }=.15 \% \\
{[\text { PLN] }}\end{array}$ & Ratio \\
\hline \hline 1 & 991 & 447.26 & 7522.75 & 17 & 3816.08 & 9 & 1141.69 & 3 \\
\hline 2 & 712 & 281.34 & 5816.41 & 21 & 2950.50 & 10 & 882.73 & 3 \\
\hline 3 & 1185 & 281.00 & 5813.81 & 21 & 2949.18 & 10 & 882.33 & 3 \\
\hline 4 & $237 / 1$ & 727.20 & 7593.49 & 10 & 3851.96 & 5 & 1152.43 & 2 \\
\hline 5 & $758 / 2$ & 507.78 & 4867.82 & 10 & 2469.31 & 5 & 738.76 & 1 \\
\hline 6 & 1257 & 195.62 & 4359.29 & 22 & 2211.35 & 11 & 661.59 & 3 \\
\hline 7 & 637 & 233.46 & 5299.18 & 23 & 2688.12 & 12 & 804.23 & 3 \\
\hline 8 & 1572 & 533.40 & 6587.50 & 12 & 3341.65 & 6 & 999.75 & 2 \\
\hline 9 & 969 & 222.44 & 5708.95 & 26 & 2895.99 & 13 & 866.42 & 4 \\
\hline 10 & 735 & 564.74 & 5373.16 & 10 & 2725.65 & 5 & 815.46 & 1 \\
\hline \hline
\end{tabular}

Results of proposed methodology for estimating tax rates is illustrated in graph below (Fig. 2), where additional lines parallel to $X$, indicated average rates charged to each zone appraisal 219-Wilkowyja.

\section{Graph of estimated tax levels cadastral}

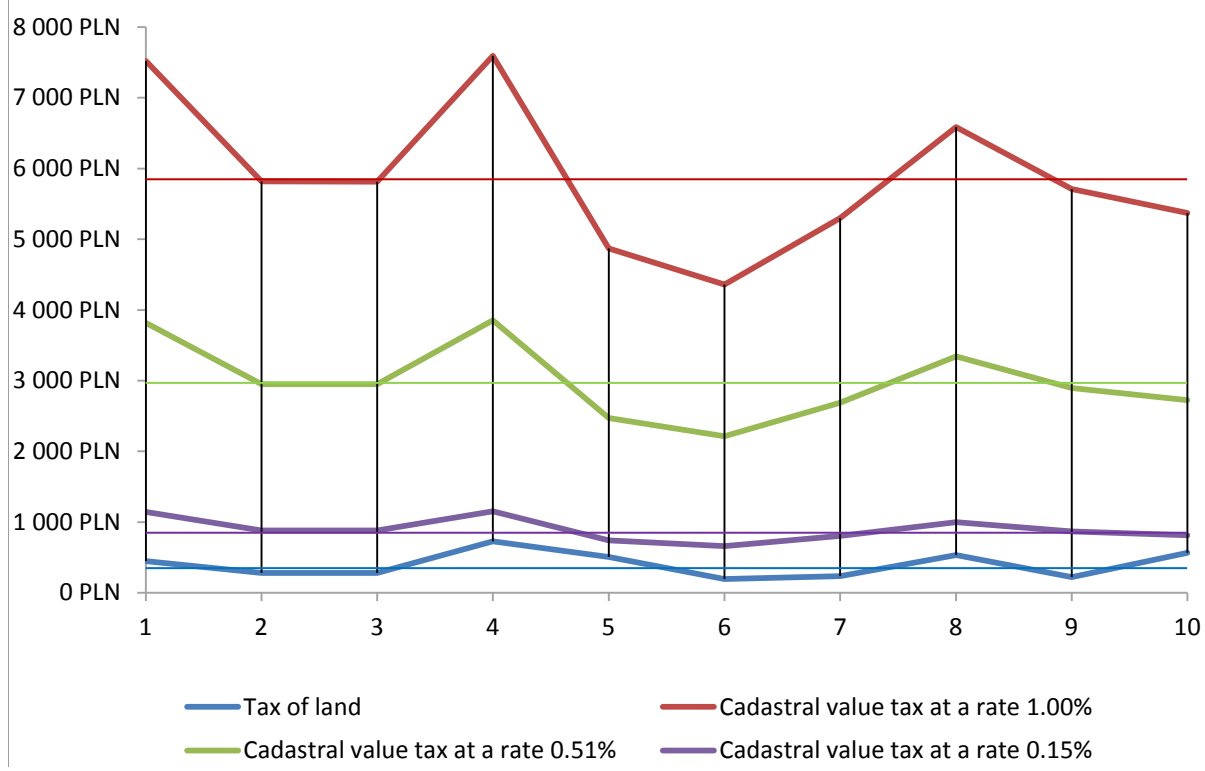

Fig. 2. Chart cadastral tax levels in terms of tax dependent of area 


\section{Conclusions}

Due to very large and growing indebtedness of local governments as well as due to empirical data (meaningful, as calculated uniformly for each country), collected from European Statistical Office, one can conclude that the cadastral tax will be introduced already by 2020, because is great tool to reconstruction national economy, but them wrong implementation raises deterioration quality life poorer social layers. The proposed solution includes all benefits of cadastral tax forms, eliminating portion its drawbacks, including: an increase in rental costs, potential occurrence of mass selling real estate by persons with low incomes or even several fold increase cadastral tax for tax on real estate area. Developed methodology provides tax rate nationwide basis, running at 5.1\%o, determined on basis of data collected by European Statistical Office. Based on estimated value of land registry, rate converted adequately to appraisal area Wilkowyja for which the regional tax rate was $1.5 \%$.

It is worth noting that the estimated cadastral value has a "relatively short period of validity," because now underlying rate of real estate market is characterized by large fluctuations in transaction prices. However, apart from need to update cadastral value, which should relate to property market value [16], there is also a need to re-(annual) determination tax base, taking into account macro-economic factors prevailing in country at the moment.

To sum up this development and parallel in response to question posed in introduction should be noted that proposed methodology for carrying out process interpretation-calculation for determining amount of tax rates cadastral maps the fiscal capacity of Polish society, i.e., average ratio of futuristic to current tax system does not exceed three, which in terms of emerging speculation at a rate of one percent, is a satisfactory compromise. Can therefore be concluded that implementation of such a tax charged at ad valorem tax would not require a fundamental change in financial policy of the country.

\section{References}

[1] Barańska A.: Real Estate Mass Appraisal in Selected Countries - Functioning Systems and Proposed Solutions. Real Estate Management and Valuation, vol. 21, no. 3, pp. 35-42.

[2] Czaja J.: Metody szacowania wartości rynkowej i katastralnej nieruchomości. KOMP-SYSTEM, Kraków 2001.

[3] Czaja J., Parzych P.: Zaawansowane modele statystyczne wyceny nieruchomości zurbanizowanych. Studia i Materiały Towarzystwa Naukowego Nieruchomości, vol. 16, no. 3, 2008, pp. 7-18.

[4] Data from European Statistical Office, [on-line:] http://epp.eurostat.ec.europa.eu/portal/page/portal/eurostat/home/. 
[5] Hopfer A.: Metody masowej wyceny. Warszawa 2008.

[6] IAAO International Association of Assessing Officers: Standard on Mass Appraisal of Real Property. Kansas City, Missouri, USA 2012.

[7] Cadastral tax. How does the world? Is introduce in Poland? [on-line:] http://nczas.com/wazne/podatek-katastralny-na-swiecie-czy-wprowadzac-w-polsce/.

[8] Table of average exchange rates foreign currencies. [on-line:] http://www.nbp.pl/kursy/kursya.html.

[9] Parzych P.: Modelling of Urban Estates' Values. Geomatics and Environmental Engineering, vol. 5, no. 4, 2011, pp. 63-72.

[10] Rozporzadzenie Rady Ministrów z dnia 21 września 2004 roku w sprawie wyceny nieruchomości. Dz.U. 2004 nr 207, poz. 2109 with amendments.

[11] Rozporzadzenie Rady Ministrów z dnia 29 czerwca 2005 r. w sprawie powszechnej taksacji nieruchomości. Dz.U. $2005 \mathrm{nr}$ 131, poz. 1092 with amendments.

[12] Sawiłow E.: Metodyka ustalania wartości katastralnej. Studia i Materiały Towarzystwa Naukowego Nieruchomości, vol. 16, 2008, pp. 89-102.

[13] Uchwała $n r$ XLII/804/2012 Rady Miasta Rzeszowa z dnia 13 listopada 2012 r. w sprawie wysokości stawek podatku od nieruchomości. [on-line:]

http://bip.erzeszow.pl/file/34522/stawki\%20na\%202013\%20-\%20podatek\%20 od\%20nieruchomosci.pdf.

[14] Ustawa z dnia 23 kwietnia 1964 r. - Kodeks cywilny. Dz.U. 1964 nr 16, poz. 93 with amendments.

[15] Ustawa z dnia 12 stycznia 1991 r. o podatkach $i$ opłatach lokalnych. Dz.U. 1991 nr 9, poz. 31 with amendments.

[16] Ustawa z dnia 21 sierpnia 1997 r. o gospodarce nieruchomościami. Dz.U. 1997 nr 115, poz. 741 with amendments.

[17] Założenia Krajowej Polityki Miejskiej do roku 2020. [on-line:] http://www.mrr.gov.pl/aktualnosci/polityka_rozwoju/Documents/Zalozenia_KPM_20_lipca_po_uwagach_MMN.pdf. 